\section{Folasade Esther Jimola, Graceful Onovughe Ofodu \\ Ekiti State University, Nigeria}

2019, Vol. 16 (2), 33-48(140)

revije.ff.uni-lj.si/elope

https://doi.org/10.4312/elope.16.2.33-48

UDC: $811.111^{\prime} 243: 37.091 .3$

\title{
ESL Teachers and Diagnostic Assessment: Perceptions and Practices
}

\begin{abstract}
Diagnostic assessment is an indispensable aspect of pedagogy. Past research has shown that teachers' perceptions and attitudes to diagnostic assessment could influence their classroom practices. This article discusses teachers' perceptions of diagnostic assessment, reiterates the essence of diagnostic assessment in English language classrooms, explores teachers' attitudes and utilization of diagnostic assessment techniques, and also investigates the factors influencing teachers' knowledge of assessment practices. To achieve these objectives, an empirical study on English language teachers' perceptions of diagnostic assessment, teachers' attitudes and utilization of diagnostic assessment techniques and factors influencing teachers' knowledge of assessment practices was conducted. The results show that the majority of English language teachers in the sample have inaccurate perceptions of the purpose of diagnostic assessment and also have negative attitudes to diagnostic assessment in classrooms. The results of the survey indicate that schooling, professional coursework and context are factors that influence ESL teachers' classroom assessment practices.
\end{abstract}

Keywords: English as a Second Language (ESL); diagnostic assessment; perception; attitude; utilization

\section{Učitelji angleščine kot drugega jezika in diagnostično ocenjevanje: Stališča in izkušnje}

POVZETEK

Diagnostično ocenjevanje je nepogrešljiv del poučevanja. Raziskave so pokazale, da učiteljeva stališča do diagnostičnega ocenjevanja vplivajo na njihovo prakso ocenjevanja v razredu. $\mathrm{V}$ prispevku so predstavljena stališča učiteljev do diagnostičnega ocenjevanja, diagnostično ocenjevanje pri pouku angleščine, učiteljeva uporaba tehnik diagnostičnega ocenjevanja in dejavniki, ki vplivajo na znanje učiteljev o ocenjevanju. Za dosego teh ciljev je bila izvedena empirična raziskava, ki je preučevala stališča učiteljev angleščine do diagnostičnega ocenjevanja, učiteljevo rabo tehnik diagnostičnega ocenjevanja in dejavnike, ki vplivajo na znanje učiteljev o ocenjevanju. Rezultati kažejo, da ima večina anketiranih učiteljev nepravilne zaznave o namenu diagnostičnega ocenjevanja ter negativna stališča do diagnostičnega ocenjevanja pri pouku. Rezultati nakazujejo, da so šolanje, profesionalno delo in kontekst poučevanja dejavniki, ki vplivajo na prakso ocenjevanja v razredu.

Ključne besede: angleščina kot drugi jezik; diagnostično ocenjevanje; stališča; praksa ocenjevanja 


\section{Introduction}

English as a Second Language (ESL) teachers need to have working knowledge of how to devise credible assessments which will "deepen student engagement in content" (Price, Pierson, and Light 2011,2) and yield valid information about learners' real performance without distorting pedagogical practices and learning objectives. Assessment should be considered alongside behavioural objectives and teaching methods during the preparation phase of instruction. Assessment should assist ESL teachers in establishing the baseline knowledge of students about the topic to be taught, and also help them gain insight into what learners already know. Assessment planned together with behavioural objectives gives clues to students' misconceptions and probable difficulties that they might encounter in the course of learning. The reverse applies in some Nigerian Public Senior Secondary Schools, where assessment is only administered at the end of the course for local and national examinations, which neither fosters students' knowledge of the content nor promotes teachers' assessment knowledge and skills.

In the Ado-Ekiti Local Government Area of Ekiti State, Nigeria, the English language is generally taught once a day, that is five times in a week, and each English language lesson lasts for 40 minutes. As such, each week Senior Secondary School students are taught English for 200 minutes, that is, 3 hours 20 minutes. At the start of the term many Nigerian teachers begin with the first topic in the scheme of work, leaving out diagnostic assessment. Reed (2006) discovered that many teachers avoid diagnostics completely and simply begin their teaching with Chapter 1 of the recommended textbook, assuming that they will get to know the students better in time. In ESL classrooms, however, many things could lead students astray. Students may have formed various inaccurate, incomplete or false opinions, conjectures, and beliefs about the concept to be learnt before stepping into their classrooms based on their observations, backgrounds, exposure and experiences. Students do not discard these misconceptions, but merely adjust the pre-existing false information to accommodate the new concept rather than wholly incorporating the correct information, which could be worse than complete ignorance. Teachers thus need to address these misconceptions as early as possible.

Moreover, in Nigeria English language teachers' assessment practices do not seem to have positively influenced students' learning nor met students' needs regarding assessment, due to various factors. One of these is that diagnostic assessment has not been sufficiently researched, as it has garnered little attention in second language assessment and education, while greater focus is placed on proficiency, achievement, formative and summative assessment (Reed 2006; Jang and Wagner 2013; Olagunju 2015; Fakeye 2016; Al-Shehri 2008;). Some of the studies conducted on diagnostic assessment centred on using diagnostic classroom assessment (Ciofalo and Wylie 2006), the relationship between students' diagnostic assessment and achievement in a pre-university instruction (Shim, Shakawi, and Azizan 2017), diagnostic teaching for primary level students (International Reading Association 2005), diagnostic assessment guide (Stevens 2009), diagnostic assessment in language teaching and learning (Reed 2006), diagnostic assessment in science as a means to improve teaching, learning and retention (Treagust 2006), diagnostic assessment to improve teaching practice (Sun and Suzuki 2013), and diagnostic assessment strategies for teachers (Chin 2001). From the 
foregoing it could be deduced that little has been done on teachers' perceptions of diagnostic assessment, attitudes to diagnostic assessment, utilization of diagnostic assessment techniques and the factors influencing teachers' knowledge of assessment practices.

Other notable factors that have contributed to English language teachers' poor assessment practices are the inadequate training of teachers, insufficient exposure of teachers to varieties of assessment techniques, the dearth of proper knowledge of assessment skills (Plake and Impara 1997; DeLuca and Klinger 2010), teachers' complacency with regard to traditional methods of assessment, and teachers' reluctance to adopt learner-centred assessment strategies. The present study stems from a need to reveal Nigerian ESL teachers' perceptions of the purpose of diagnostic assessment in classrooms, their dispositions to the use of diagnostic assessment and whether they conduct such assessment in their classrooms.

The article is structured as follows. Section 1 introduces the background to the study, while Section 2 presents the theoretical framework. Section 3 reveals the relevance of the theoretical framework to the study, and Section 4 explains diagnostic assessment. Section 5 focuses on the teachers' perceptions of the purpose of diagnostic assessment, attitudes to diagnostic assessment, utilization of diagnostic assessment techniques and factors influencing their knowledge of assessment practices. The last sections (6 and 7) discuss the results and their implications for ESL classrooms.

\section{Theoretical Framework}

The theory of teacher cognition underlies this study. Teacher cognition, which is also known as teacher knowledge, refers to the unnoticeable cognitive dimension of teaching which entails "what teachers know, believe and think" (Borg 2003). It came about in the mid1970s in the US (Borg 2009), and its perception "includes a variety of notions like teachers' knowledge, perceptions, beliefs and attitudes towards their actual performances and practices in a specific context" (Yunus, Salehi, and Amini 2016, 20). Teacher cognition emanates from four sources (i) schooling - early protracted personal experiences during initial learning as a language learner, (ii) professional coursework - attending professional activities, in-service training about curricula, subject matter, instructional activities, (iii) contextual factors, teachers' classroom experiences and practices - through exposure to classroom situations, and (iv) personality - the constructs that merged to form the thinking dimension such as attitudes, perspectives, conceptions and beliefs which exert influence on their present pedagogical practices (Borg 2003; Hill 2014; Siamak 2014; Mathiesen Gilje 2014; Chan 2015; Jamalzadeh and Shahsavar 2015).

\section{Relevance of the Theoretical Framework to the Study}

This theory is relevant to this work because teachers' classroom practices, including their perceptions, decisions, judgments and justifications with regard to assessment, are projections of their beliefs, knowledge and thoughts which are as a result of the four sources of teacher cognition (Fan 1999). Teachers are not machines, their actions and attitudes towards students' and pedagogical activities are substantially controlled by their belief systems. This thus affects their pedagogical practices, including their perceptions of 
and disposition towards various classroom assessments. In order to advance the frontiers of classroom assessment practices, the dimension of cognition therefore stresses the significance of ESL teachers "deconstructing their own prior knowledge and attitudes, comprehending how these understandings evolved; exploring the effects they have on actions and behaviour, and considering alternate conceptions and premises that may be more serviceable in teaching" (Adeosun, Oni, and Oladipo 2013, 43).

\section{Diagnostic Assessment}

Stevens (2009) asserts that the diagnostic assessment process $^{1}$ is a decision-making strategy for determining when and how to deliver instructional remediation to learners through additional instruction, and also to help teachers determine whether the students can move on to the next skill or concept to be taught, as outlined as expectations in the curriculum. Some assessment techniques that ESL teachers can employ to probe students' thinking faculty at the beginning of instruction are interviews, questionnaires, inventories, checklists, portfolios, misconception/preconception checks, background knowledge probes, discussions, presentations, $\mathrm{KWL}^{2}$ charts, observations, performance-based assessments, pre-tests, interview-based assessments, play-based assessments, concept mapping, predictobserve-explain, thought experiments, card-sorting, students' drawings, the post-box technique, surveys, student questions, brainstorming, viewfinders, and teacher questioning (Mussawy 2009; Chin 2001).

Diagnostic assessment can help teachers pinpoint students' present understanding of a subject, their competences, abilities, learning preferences and styles before teaching starts. Knowing students' strengths and weak points can help ESL teachers plan what to teach, have a focus and "plan intervention strategies in their teaching to deal with the issue" effectively (Abang and Farah 2017, 370). Diagnostic assessment helps ESL teachers monitor students' understanding of the subject matter and performance before, during and after teaching the lesson, establish any differences and examine teaching and learning effectiveness on a continuous basis. Alderson (2005) explains that diagnostic assessment is known for the following (also cf. Shim, Shakawi, and Azizan 2017):

1. a greater focus on weaknesses than on strengths;

2. leading to remediation in further instruction;

3. providing detailed feedback which can be acted upon;

4. being based on content covered in instruction;

5. being discrete-point rather than integrative, or more focused on specific elements than on global abilities.

Alderson, Brunfaut and Harding $(2014,318)$ explain that "diagnostic assessment should ideally be embedded within a system that allows for all four diagnostic stages: (1) listening/ observation, (2) initial assessment, (3) use of tools, tests, expert help, and (4) decision- 
making." Diagnostic assessment determines a student's current level when he or she enters a new school or "at specified times during the school term to help shape teaching strategies" (Organisation for Economic Co-operation and Development 2005, 3). Teachers may employ diagnostic assessment to detect students' abilities and comprehension of language skills; listening, speaking, reading, writing, linguistics and grammar structures.

In Nigeria, there are deficiencies in speaking the target language 3 due to the structural differences between Nigerian and English. Consequently, most Nigerian learners of English have problems with the pronunciation of English words. Some notable pronunciation problems are found in the use of consonants, substitution, consonant cluster(s), initial and final consonants, vowels, vowel shortening and lengthening, spelling-pronunciation, and prosody (Bamisaye 2006). Explanations of linguistic concepts should be complemented with guiding questions that could improve students' thinking skills. This task is quite different from a situation where a teacher asks content questions to which the answers are easily located in a textbook or known (Intel Corporation 2014). The use of diagnostic assessment could help English language teachers discover grey areas and remediate where necessary and foster and strengthen further instruction, leading to better decisions about where and when to focus instructional time and exert effort in the classroom.

\section{The Study}

\subsection{Aims of the Study}

The study aimed at examining English language teachers' perceptions of diagnostic assessment, their attitudes to and utilization of diagnostic assessment techniques, and factors influencing their knowledge of assessment practices.

\subsection{Research Questions}

The following research questions were formulated to guide the study:

1. How do English language teachers perceive the purpose of diagnostic assessment?

2. What is the attitude of English language teachers towards the use of diagnostic assessment?

3. To what extent do English language teachers utilize diagnostic assessment techniques in the classroom?

4. What factor(s) mainly influence English language teachers' assessment practices?

\subsection{Method}

This study adopted a descriptive research design using a survey. This was considered suitable because the purpose was to collect information on the existing situation and describe the phenomenon according to the reports of the respondents.

English language, which is the target language, is the official language and second language of most Nigerians. 


\subsection{Participants}

Fifty respondents who were English language teachers in public senior secondary schools in the Ado-Ekiti Local Government Area of Ekiti State, Nigeria, participated in the study, which took place in 2018. The ages of the teachers who participated ranged from 25 to 50, while the ages of the senior secondary schools students they taught ranged from 14-16. Fifty-six percent of the participants were female, while forty-four percent were male. The respondents' years of work experience were in the range of $1-35$ years.

\subsection{Instrument and Procedure}

One research instrument was used for data collection. Sixty questionnaires were distributed in hard copies in senior secondary schools in Ado-Ekiti Metropolis, Nigeria, and 50 were completed and returned. Respondents were given adequate time to fill out the questionnaires. The questionnaire was titled "Questionnaire on Teachers' Perceptions and Utilization of Diagnostic Assessment in English Language Classrooms". This questionnaire was divided into two sections. Section A dealt with the demographic information of the respondents, that is, gender, age and years of work experience, while the items on section B were subdivided into groups A, B and C. Group A addressed teachers' perceptions of and attitude to diagnostic assessment in English language classrooms with 22 items. This part was measured using a four-point-Likert-type scale (Strongly Agree (SA), Agree (A), Strongly Disagree (D) and Strongly Disagree (SD). Group B focused on utilization of diagnostic assessment techniques in English language classrooms, with 10 classroom assessment activities. In this part, the respondents were asked to respond by ticking the types of activities they used for conducting diagnostic assessment in classrooms choosing 'never', 'rarely', 'sometimes' and 'always' as applicable. Group C focused on factor(s) that influenced English language teachers' knowledge of classroom assessment practices. This part was measured using a four-point Likert-type scale ranging from Strongly Agree (SA), Agree (A), Strongly Disagree (D) to Strongly Disagree (SD).

\subsection{Validity and Reliability of the Instrument}

The face and content validity of the instrument was ascertained by experts in language, testing, measurement and evaluation. Thorough scrutiny of the instrument was carried out and the necessary corrections, suggestions and comments were made before the final draft was judged valid for the study. The reliability of the questionnaire on teachers' perceptions and utilization of diagnostic assessment in English language was ensured by administering this instrument to 20 English language teachers selected outside the sample of the study. The reliability of the instrument was estimated through a test-retest method using Pearson's Product Moment Correlation and a reliability coefficient of 0.81 was obtained.

\section{Results}

The results are discussed in four sections according to the target research areas, as presented below. 


\subsection{Teachers' Perceived Purpose of Diagnostic Assessment}

As shown in Table 1, 32 teachers (64\%) perceived that the purpose of diagnostic assessment is to assign marks to students, while $37(74 \%)$ stated that diagnostic assessment is about ranking of students at the end of each term. Thirty-six teachers (72\%) supported the statement that the purpose of diagnostic assessment is to detect students' comprehension of the lesson at the end of the task, while 32 (64\%) agreed that the purpose of diagnostic assessment is not to spot students' strengths. Thirty-eight (74\%) claimed that diagnostic assessment establishes the exact nature of the specific learning difficulties at the end of the task, and 33 (66\%) agreed that the purpose of diagnostic assessment is to marshal further instruction for remediation. Moreover, 34 (68\%) and 39 teachers (78\%), respectively, agreed that diagnostic assessment fosters students' engagement in learning and contributes immensely to the improvement of the learning and teaching practices.

TABLE 1. Teachers' perceived purpose of diagnostic assessment $\mathrm{N}=50$.

\begin{tabular}{|c|c|c|c|c|c|c|}
\hline $\mathrm{S} / \mathrm{N}$ & Items & $\begin{array}{l}\text { Strongly } \\
\text { Agree (SA) }\end{array}$ & $\begin{array}{l}\text { Agree } \\
\text { (A) }\end{array}$ & $\begin{array}{l}\text { Disagree } \\
\text { (D) }\end{array}$ & $\begin{array}{l}\text { Strongly } \\
\text { Disagree } \\
\text { (SD) }\end{array}$ & Mean \\
\hline 1 & Assign marks to students. & $14(28 \%)$ & $18(36 \%)$ & $10(20 \%)$ & $8(16 \%)$ & 2.76 \\
\hline 2 & $\begin{array}{l}\text { Rank students at the end } \\
\text { of each term. }\end{array}$ & $20(40 \%)$ & $17(34 \%)$ & $7(14 \%)$ & $6(12 \%)$ & 3.02 \\
\hline 3 & $\begin{array}{l}\text { Detect students' } \\
\text { comprehension of the } \\
\text { lesson at the end of the } \\
\text { task. }\end{array}$ & $19(38 \%)$ & $17(34 \%)$ & $8(16 \%)$ & $6(12 \%)$ & 2.98 \\
\hline 4 & $\begin{array}{l}\text { It is not to spot students' } \\
\text { strengths. }\end{array}$ & $15(30 \%)$ & $17(34 \%)$ & $10(20 \%)$ & $8(16 \%)$ & 2.78 \\
\hline 5 & $\begin{array}{l}\text { Establish the exact nature } \\
\text { of the specific learning } \\
\text { difficulties at the end of } \\
\text { the task. }\end{array}$ & $21(42 \%)$ & $16(32 \%)$ & $8(16 \%)$ & $5(10 \%)$ & 3.06 \\
\hline 6 & $\begin{array}{l}\text { Marshal further } \\
\text { instruction for } \\
\text { remediation. }\end{array}$ & $15(30 \%)$ & $18(36 \%)$ & $9(18 \%)$ & $8(16 \%)$ & 2.80 \\
\hline 7 & $\begin{array}{l}\text { Foster students' } \\
\text { engagement in learning. }\end{array}$ & $14(28 \%)$ & $20(40 \%)$ & $9(18 \%)$ & $7(14 \%)$ & 2.82 \\
\hline 8 & $\begin{array}{l}\text { Contribute immensely } \\
\text { to the improvement of } \\
\text { the learning and teaching } \\
\text { practices. }\end{array}$ & $21(42 \%)$ & $18(36 \%)$ & 7 (14\%) & $4(8 \%)$ & 3.12 \\
\hline
\end{tabular}




\subsection{Attitude of English Language Teachers towards Diagnostic Assessment}

In Table 2, the results show that 33 teachers $(66 \%)$ considered diagnostic assessment as time consuming, $40(80 \%)$ indicated that they do not plan in advance for assessment techniques to be used during the preparation phase of instruction, but they think of assessment after the end of the course, i.e. as a form of summative assessment. The results indicate that 40 teachers $(80 \%)$ rarely used diagnostic assessment to evaluate students' prior knowledge. They also reveal that $28(56 \%)$ and 33 teachers $(66 \%)$, respectively, do not like asking questions before starting the lesson and claimed that diagnostic assessment makes their class boring. Similarly, 35 (70\%) and 33 teachers (66\%), respectively, claimed that diagnostic assessment would disrupt their lesson if utilized and considered it very tedious to administer promptly and regularly.

The results further show that 41 teachers $(82 \%)$ do not give diagnostic assessments because of the large class size, while $25(50 \%)$ disagreed that diagnostic assessment demoralizes students. The results also indicate that 45 teachers (90\%) affirmed that diagnostic assessment helps them in knowing their students' readiness, whereas 35 (70\%) do not consider diagnostic assessment as important as formative and summative assessments. Moreover, 41 (82\%) agreed that diagnostic assessment increases the workload of teachers. Thirty-three (66\%) of the participants claimed that they do not conduct assessment before they begin a topic, while $33(66 \%)$ affirmed that they do not conduct assessment at the beginning of each term.

TABLE 2. Attitude of English language teachers towards diagnostic assessment $\mathrm{N}=50$.

\begin{tabular}{|l|l|l|l|l|l|l|}
\hline S/N & Items & $\begin{array}{l}\text { Strongly } \\
\text { Agree } \\
\text { (SA) }\end{array}$ & Agree (A) & $\begin{array}{l}\text { Disagree } \\
\text { (D) }\end{array}$ & $\begin{array}{l}\text { Strongly } \\
\text { Disagree } \\
\text { (SD) }\end{array}$ & Mean \\
\hline 1 & $\begin{array}{l}\text { Diagnostic assessment is } \\
\text { time consuming. }\end{array}$ & $18(36 \%)$ & $15(30 \%)$ & $10(20 \%)$ & $7(14 \%)$ & 2.88 \\
\hline 2 & $\begin{array}{l}\text { I plan for assessment } \\
\text { technique to be used } \\
\text { after the end of the } \\
\text { course. }\end{array}$ & $22(44 \%)$ & $18(36 \%)$ & $5(10 \%)$ & $5(10 \%)$ & 3.14 \\
\hline 3 & $\begin{array}{l}\text { I rarely use diagnostic } \\
\text { assessment to evaluate } \\
\text { students prior } \\
\text { knowledge. }\end{array}$ & $21(42 \%)$ & $19(38 \%)$ & $6(12 \%)$ & $4(8 \%)$ & 3.14 \\
\hline 4 & $\begin{array}{l}\text { I do not like asking } \\
\text { questions before } \\
\text { commencing the lesson. }\end{array}$ & $13(26 \%)$ & $15(30 \%)$ & $10(20 \%)$ & $12(24 \%)$ & 2.58 \\
\hline 5 & $\begin{array}{l}\text { Diagnostic assessment } \\
\text { makes my class boring. }\end{array}$ & $17(34 \%)$ & $16(32 \%)$ & $11(22 \%)$ & $6(12 \%)$ & 2.88 \\
\hline
\end{tabular}




\begin{tabular}{|l|l|l|l|l|l|l|}
\hline S/N & Items & $\begin{array}{l}\text { Strongly } \\
\text { Agree } \\
\text { (SA) }\end{array}$ & Agree (A) & $\begin{array}{l}\text { Disagree } \\
\text { (D) }\end{array}$ & $\begin{array}{l}\text { Strongly } \\
\text { Disagree } \\
\text { (SD) }\end{array}$ & Mean \\
\hline 6 & $\begin{array}{l}\text { Diagnostic assessment } \\
\text { would disrupt my lesson. }\end{array}$ & $20(40 \%)$ & $15(30 \%)$ & $6(12 \%)$ & $9(18 \%)$ & 2.92 \\
\hline 7 & $\begin{array}{l}\text { Diagnostic assessment } \\
\text { is very tedious to } \\
\text { administer promptly and } \\
\text { regularly. }\end{array}$ & $19(38 \%)$ & $14(28 \%)$ & $7(14 \%)$ & $10(20 \%)$ & 2.84 \\
\hline 8 & $\begin{array}{l}\text { I do not give diagnostic } \\
\text { assessment because of } \\
\text { the large class size. }\end{array}$ & $20(40 \%)$ & $21(42 \%)$ & $4(8 \%)$ & $5(10 \%)$ & 3.12 \\
\hline 9 & $\begin{array}{l}\text { Diagnostic assessment } \\
\text { might demoralize } \\
\text { students. }\end{array}$ & $12(24 \%)$ & $13(26 \%)$ & $12(24 \%)$ & $13(26 \%)$ & 2.48 \\
\hline 10 & $\begin{array}{l}\text { Diagnostic assessment } \\
\text { helps me in knowing my } \\
\text { students readiness. }\end{array}$ & $22(44 \%)$ & $23(46 \%)$ & $2(4 \%)$ & $3(6 \%)$ & 3.28 \\
\hline 11 & $\begin{array}{l}\text { Diagnostic assessment } \\
\text { is not as important } \\
\text { as formative and } \\
\text { summative assessments. }\end{array}$ & $20(40 \%)$ & $15(30 \%)$ & $6(12 \%)$ & $9(18 \%)$ & 2.92 \\
\hline 12 & $\begin{array}{l}\text { Diagnostic assessment } \\
\text { increases teachers' } \\
\text { workload. }\end{array}$ & $20(40 \%)$ & $21(42 \%)$ & $4(8 \%)$ & $5(10 \%)$ & 3.12 \\
\hline 13 & $\begin{array}{l}\text { I do not conduct } \\
\text { assessment before I begin } \\
\text { a topic }\end{array}$ & $17(34 \%)$ & $16(32 \%)$ & $11(22 \%)$ & $6(12 \%)$ & 2.88 \\
\hline 14 & $\begin{array}{l}\text { I do not conduct } \\
\text { assessment at the } \\
\text { beginning of each term }\end{array}$ & $18(36 \%)$ & $15(30 \%)$ & $10(20 \%)$ & $7(14 \%)$ & 2.88 \\
\hline
\end{tabular}

\subsection{English Teachers' Utilization of Diagnostic Assessment Techniques in the Classroom}

Table 3 shows that all 50 (100\%) of the teachers do not use questionnaires for diagnostic assessment, while $40(80 \%)$ use oral interviews for this purpose. The results also reveal that all $50(100 \%)$ do not use misconception checks for diagnostic assessment in the classroom, but $37(74 \%)$ use discussions. The results further reveal that all $50(100 \%)$ and $48(96 \%)$, respectively, never use checklists, portfolios or inventories as diagnostic assessment techniques. In contrast, $33(66 \%)$ and $45(90 \%)$ agreed that they use observation and questioning techniques, respectively, while $40(80 \%)$ stated that they do not use written pre-tests for diagnostic assessment. Thus, the majority of the English language teachers who participated in the survey use oral interviews, discussions, observation and questioning for such assessments. 
TABLE 3. English teachers' utilization of diagnostic assessment techniques in the classroom $\mathrm{N}=50$.

\begin{tabular}{|c|c|c|c|c|c|c|}
\hline $\mathrm{S} / \mathrm{N}$ & $\begin{array}{l}\text { Diagnostic } \\
\text { assessment } \\
\text { techniques }\end{array}$ & Never & Rarely & Sometimes & Always & Mean \\
\hline 1 & Questionnaires & $50(100 \%)$ & - & - & - & 1.0 \\
\hline 2 & Oral interviews & $3(6 \%)$ & $7(14 \%)$ & $15(30 \%)$ & $25(50 \%)$ & 3.24 \\
\hline 3 & $\begin{array}{l}\text { Misconception } \\
\text { checks }\end{array}$ & $50(100 \%)$ & - & - & - & 1.0 \\
\hline 4 & Discussions & $7(14 \%)$ & $6(12 \%)$ & $17(34 \%)$ & $20(40 \%)$ & 3.0 \\
\hline 5 & Checklists & $50(100 \%)$ & - & - & - & 1.0 \\
\hline 6 & Portfolios & $46(92 \%)$ & $2(4 \%)$ & $1(2 \%)$ & $1(2 \%)$ & 1.14 \\
\hline 7 & Inventories & $45(90 \%)$ & $3(6 \%)$ & $2(4 \%)$ & - & 1.14 \\
\hline 8 & Observation & $2(4 \%)$ & $10(20 \%)$ & $20(40 \%)$ & $18(36 \%)$ & 3.08 \\
\hline 9 & Questioning & - & $5(10 \%)$ & $18(36 \%)$ & $27(54 \%)$ & 3.44 \\
\hline 10 & Written Pre-tests & $30(60 \%)$ & $10(20 \%)$ & $5(10 \%)$ & $5(10 \%)$ & 1.70 \\
\hline
\end{tabular}

6.4 Factors Influencing English Language Teachers' Classroom Assessment Practices

Using the cut-off mean of 2.50, Table 4 reveals that schooling $(\mathrm{M}=3.14)$, professional coursework $(M=3.12)$ and contextual factors $(M=2.88)$ are the main factors influencing teachers' knowledge of classroom assessment practices, while personality $(M=2.48)$ has the lowest mean.

TABLE 4. Factors influencing English language teachers' classroom assessment practices $\mathrm{N}=50$.

\begin{tabular}{|l|l|l|l|l|l|l|}
\hline S/N & $\begin{array}{l}\text { Factors influencing } \\
\text { teachers' assessment } \\
\text { practices }\end{array}$ & $\begin{array}{l}\text { Strongly } \\
\text { Agree (SA) }\end{array}$ & $\begin{array}{l}\text { Agree } \\
(\mathbf{A})\end{array}$ & $\begin{array}{l}\text { Disagree } \\
(\mathbf{D})\end{array}$ & $\begin{array}{l}\text { Strongly } \\
\text { Disagree } \\
(\text { SD })\end{array}$ & Mean \\
\hline 1 & Schooling & $22(44 \%)$ & $18(36 \%)$ & $5(10 \%)$ & $5(10 \%)$ & 3.14 \\
\hline 2 & $\begin{array}{l}\text { Professional } \\
\text { coursework }\end{array}$ & $21(42 \%)$ & $18(36 \%)$ & $7(14 \%)$ & $4(8 \%)$ & 3.12 \\
\hline 3 & Contextual factors & $17(34 \%)$ & $16(32 \%)$ & $11(22 \%)$ & $6(12 \%)$ & 2.88 \\
\hline 4 & Personality & $12(24 \%)$ & $13(26 \%)$ & $12(24 \%)$ & $13(26 \%)$ & 2.48 \\
\hline
\end{tabular}




\section{Discussion}

The present study reveals that some English language teachers in senior secondary school in Ado-Ekiti, Nigeria, do not have sufficient knowledge of what diagnostic assessment entails nor the reasons for conducting it. Most of the respondents stated erroneously that diagnostic assessment is only meant to assign marks to students or rank them at the end of each term, and it is not meant to spot students' strengths. Although they are aware that diagnostic assessment establishes the exact nature of a student's specific learning difficulties, they felt that it should only take place at the end of the teaching task. However, diagnosing students' learning outcomes should not only be assessed at the end of the teaching task. The respondents affirmed that diagnostic assessment marshals further instructions for remediation, fosters students' engagement in learning and contributes immensely to the improvement of both learning and teaching practices. This is supported by Susuwele-Banda (2005), which found that classroom assessment is perceived by teachers as tests given at the end of a topic or at the end of a term, and teachers prefer to check up on students' mastery of the focal subject matter at the end of the term, and not necessarily to help students learn.

It is vital to check if students have achieved the stated learning objectives at the end of the lesson, assessing them at end of the term might be too late to address students' learning problems. Nikolov (2016) in states that after carrying out tasks in the classroom learners could be questioned about the extent to which they like or dislike the tasks, how familiar they are with the tasks, and whether they find them easy or difficult. She notes that when teachers provide a forum for learners to participate in discussions after accomplishing tasks, this could help teachers "gain valuable insights into their learners' experiences, they may be able to tailor their teaching to the needs of the learners, and they may also develop their young language learners' self-assessment and autonomy' problems" (Nikolov 2016, 23). Pradhan (2014) explains that diagnostic assessment is the art of recognizing difficulties based on their symptoms, which if undiagnosed might limit students' engagement in new learning (Targema and Obadare-Akpata 2018). In Ounis (2017) it was shown that secondary school teachers who participated in the study were mostly interested in the accountability purpose of assessment, since it is mandatory that they assign, generate and record marks and grades to each pupil they teach. Ounis (2017) claimed that teachers' perceptions of assessment will build a basis and rationale for the type of assessment practice they employ while in the classroom.

Regarding teachers' attitude towards the use of diagnostic assessment, it could be inferred that the English language teachers who participated in this study exhibited negative attitudes towards the use of diagnostic assessment. The majority of the respondents claimed that they rarely use diagnostic assessment to evaluate students' prior knowledge, because it is time consuming, makes their class boring and is very tedious to administer. A larger percentage of the respondents in the study affirmed that diagnostic assessment gave them clues with regard to students' readiness to learn, yet they also felt that it is time consuming, demoralizing, boring and increases their workload. Rarely did they use diagnostic assessment to assess students' prior knowledge, and they preferred summative assessment to other kinds. Most of the respondents revealed that they do not conduct assessment before they begin a topic or 
at the beginning of each term. In the research carried out by Sethusha (2012), Ofodu and Owolewa (2018), Pereira and Flores (2016), it was found that teachers complained of some of the challenges affecting their classroom assessment practices. One of these is insufficient time, and the use of learner-centred assessment techniques would put more pressure on this. The results of this research are also in line with Treagust $(2006,1)$, who explains that the difficulty encountered with most effective assessment methods is that "they are very time consuming and rarely practical for busy classroom teachers to create".

Another reason given by the participants in this study as responsible for their attitude towards diagnostic assessment is the large class size. The respondents revealed that diagnostic assessment could disrupt their lesson if utilized, and they considered it very tedious to administer due to the problem of large class size. In senior secondary schools in Ado-Ekiti, Ekiti State, Nigeria, there are three classes, namely SSS1, SSS2, and SSS3, and each class consists of three arms. ${ }^{4}$ In some schools where they are understaffed, an English language teacher could teach several arms in a day. This situation is worrisome and might not give English language teachers the opportunity to accord appropriate attention to individual learners. Consequently, English language teachers might push aside diagnostic assessment. This is supported by Pereira and Flores (2016), who affirm that teachers resist the use of certain forms of assessment and participatory methods due to the number of students per class, lack of resources, and already heavy workload. Moreover, Targema and Obadare-Akpata $(2018,22)$ note some challenges facing "the use of diagnostic assessment for quality control in education", such as the problem of large class size, lack of a motivation mechanism for teachers and the dearth of enthusiastic and dedicated teachers. Walsh and Wyatt (2014) reported how the assessment technique utilized by one of the participants influenced her to such an extent that there was an observed lack of fit between practices and stated principles, and how contextual factors, such as an obsession with tests, could lead a teacher away from classroom practices.

In the present study, most of the respondents stated that diagnostic assessment is not as important as formative and summative assessments. It is obvious that teachers' attitude towards the use of diagnostic assessment is rather negative. Due to their many obligations, teachers are more interested in teaching the contents of the syllabus and using summative assessment to find out if students have learnt these and to evaluate the students' performance. Some English language teachers prefer summative assessment because it is compulsory, seen as proof of students' performance, and also used for promoting a student to another class at a higher level.

It is observed in other studies that most ESL teachers are accustomed to certain assessment methods, such as paper and pencil tests, avoiding other techniques (Chin 2001; Dandis 2013; Asale 2017). Although these classroom assessment strategies, such as questionnaires, checklists, portfolios, misconception/preconception checks, pre-tests and predict-observeexplain may be time-consuming, researchers have found that they are useful in identifying students' learning problems, depending on the teachers' ability to schedule their time for assessment appropriately.

\footnotetext{
'SSS' means senior secondary school, it is the level of education after primary education and before the tertiary stage (Federal Republic of Nigeria 2004); 'arms' means the subdivision of classes in senior secondary schools into different fields of studies (Science, Commercial and Humanities).
} 
This study found that the majority of English language teachers in the survey track students' strengths and weaknesses via oral interviews, discussions, observation and questioning, while questionnaires, misconception checks, checklists, portfolios, inventory and written pre-test were not used. Similar results were observed in different subject areas, for example Asale (2017) confirms that teachers do not use the variety of assessment techniques available in teaching mathematics. Pereira and Flores $(2016,23)$ elaborate the conceptions and practices of assessment in higher education, stating that "written tests continue to be the most used method identified by the participants." This is also in agreement with the results of Ofodu and Owolewa (2018), who evaluated the linguistic and pedagogical skills of English language teachers in Ado-Ekiti, Nigeria. They find that most English language teachers made use of written examinations to measure learning capacity, while checklists are rarely used as an evaluation tool in English lessons.

A large percentage of the respondents in the present study responded that schooling (personal experience during initial learning as a language learner), professional coursework (attending professional activities, in-service training about curricula, subject matter, instructional activities), contextual factors (teachers' classroom experiences and practices) influence their classroom assessment practices. In contrast, personality (attitudes, perspectives, conceptions and beliefs) was not reported to have influenced their classroom assessment practices. This falls in line with Fan (1999), who claims that teachers' own teaching experience and reflection, professional activities, in-service training, and experience as school students are the most important sources of teachers' cognition.

This research was constrained by some factors such as time constraints, teachers' reluctance to participate and the lack of relevant research materials. The limited time available restricted the researcher from extending the area covered by the study to other parts of Ekiti State and even other regions of Nigeria. Moreover, some of the English language teachers who could have taken part in this study were reluctant to participate, and it took the researcher a lot of time to convince them that it was solely for research purpose and the questionnaires were confidential, not a way to find evidence of poor practices. Some of these teachers then agreed to participate, but a larger number remained disinterested as they considered the project as threat to their careers. This made the sample smaller and less representative, hence it is not possible to provide generalizations, but only hints at the broader picture.

Furthermore, the research design was descriptive and non-experimental. To the best of the author's knowledge, while there are many researchers worldwide working on diagnostic assessment there are limited numbers of home-grown studies on this topic in Ekiti State, Nigeria. Those that are available defined diagnostic assessment and its importance to pedagogy without recourse to its use and application to teaching English as a Second Language.

\section{Conclusion}

Classroom assessment in ESL is essential, as it determines when and how to deliver instructional remediation to learners through additional instruction. Besides, Erin (2009) asserts that diagnostic assessment could help teachers identify students for additional school services, including tests of cognitive functioning, behaviour, social competence, language 
ability, and academic achievement. However, despite this, some Nigerian ESL teachers do not realize the importance of diagnostic assessment in ESL classrooms, because they believe that it is not as important as formative and summative assessment. Consequently, most of the Nigerian English language teachers who participated in this study do not administer diagnostic assessment in their classrooms, some have incorrect perceptions of the purpose of diagnostic assessment in English language classrooms, while some have a negative attitude to the use of such assessment.

Training in diagnostic assessment is vital, as it enables teachers to diagnose the problems of the students and thus better understand the teaching and learning process. Trained teachers could diagnose students at the inception of a course of study, whenever students' entry behaviour is to be determined in order to assess their prior knowledge, language skills, preconceptions, and misconceptions, and to pinpoint learners' persistent learning difficulties in any aspect of the English language. This could afford the teacher the opportunity to discover in good time the various potentials and recurring problems that students are faced with, and as well adjust their teaching instructions to meet the learners' needs individually or collectively and offer better remedial instruction, as needed. Otherwise, if teachers avoid diagnostic assessment or postpone it to a later time it may have harmful effects on learners. In the long run, by the time teachers get acquainted with the students and discover their strengths and weaknesses it may already be too late too help them.

The results of this study could be useful for English language teachers, students and curriculum designers. For teachers, this study may remind them of the importance and essence of diagnostic assessment in the English classroom. For students, it may help them overcome a fear of assessment. Finally, curriculum designers would be aware of English language teachers' perceptions of the purpose of diagnostic assessment and utilization of diagnostic assessment techniques. They can thus focus on teachers' perceptions of and attitude to the use of diagnostic assessment, and reiterate the essence of this important technique in pedagogy.

\section{References}

Adeosun, Oyenike, Soji Oni, and Bayo Oladipo. 2013. "Affective and Cognitive Characteristics of Nigerian Student-Teachers: Towards Developing an Effective Teacher Education Framework." Journal of International Cooperation in Education 15 (3): 39-58. http://doi.org/10.15027/34864.

Alderson, J. Charles. 2005. Diagnosing Foreign Language Proficiency: The Interface Between Learning and Assessment. London: Continuum.

Alderson, J. Charles, Tineke Brunfaut, and Luke Harding. 2014. "Towards a Theory of Diagnosis in Second and Foreign Language Assessment: Insights from Professional Practice across Diverse Fields.” Applied Linguistics: 36 (2): 236-60. https://doi.org/10.1093/applin/amt046.

Al-Shehri, Khaloufa Dhafer. 2008. “Teachers' and Students' Attitudes Toward Formative Assessment and Feedback in Teaching English for Specific Purposes ESP.” MA thesis, University of Glasgow.

Asale, Temesgen Samuel. 2017. "Teachers' Perception and Practices towards Continuous Assessment of Mathematics Classes: The Case of Secondary School in Wolaita Zone, Southern Nations Nationalities Peoples Region." Journal of Education and Practice 8 (22): 84-109. https://www.iiste.org/Journals /index.php/JEP/article/view/38312/39386.

Bamisaye, Toyin O. 2006. Oral English for ESL learners. First Edition. Lagos: Jones Publications. 
Borg, Simon. 2003. "Teacher Cognition in Language Teaching: A Review of Research on What Language Teachers Think, Know, Believe, and Do." Language Teaching 36 (2): 81-109. https://doi.org/10.1017 /S0261444803001903.

—. 2009. "Introducing Language Teacher Cognition." Centre for Language Education Research, School of Education, University of Leeds. http://www.education.leeds.ac.uk/research/files/145.pdf.

Chan, Kelly Shufen. 2015. "Teacher Cognition of Experienced Taiwanese University Teachers of English." PhD diss., University of Technology, Sydney. https//opus.lib.uts.edu.au/bitstream/10453/34475/1 /01front.pdf.

Chin, Christine. 2001. "Eliciting Students' Ideas and Understanding in Science: Diagnostic Assessment Strategies for Teachers." Teaching and Learning 21 (2): 72-85.

Ciofalo, Joseph, and Caroline E. Wylie. 2006. "Using Diagnostic Classroom Assessment: One Question at a Time." Teachers College Record, January 10, 2006.

Dandis, Maha Azmi. 2013. "The Assessment Methods that are Used in a Secondary Mathematics Class." Journal for Educators, Teachers and Trainers 4 (2): 133-43.

DeLuca, Christopher, and Don A. Klinger. 2010. "Assessment Literacy Development: Identifying Gaps in Teacher Candidates' Learning.” Assessment in Education: Principles, Policy and Practice 17 (4): 419-38. https://doi.org/10.1080/0969594X.2010.516643.

Earl, Lorna M. 2003. Assessment As Learning: Using Classroom Assessment to Maximize Student Learning. Thousand Oaks, CA: Corwin.

Erin, Caffrey D. 2009. Assessment in Elementary and Secondary Education: A Primer. Washington, DC: Congressional Research Service.

Fakeye, David O. 2016. “Secondary School Teachers' and Students' Attitudes Towards Formative Assessment and Corrective Feedback in English Language in Ibadan Metropolis." Journal of Educational and Social Research 6 (2): 141-48. https://doi.org/10.5901/jesr.2016.v6n2p141.

Fan, Lianghuo. 1999. “The Sources of Teachers' Knowledge of Instructional Materials.” The Mathematics Educator 4 (2): 42-69. http://math.nie.edu.sg/ame/matheduc/tme/tmeV4_2/book4n2pg3.pdf.

Federal Republic of Nigeria. 2004. National Policy on Education. Abuja: Nigerian Educational Research and Development Council Press.

—. 2014. National Policy on Education. Abuja: Nigerian Educational Research and Development Council Press.

Hill, Stacy Lee. 2014. “Teacher Cognition: Four Case Studies of Teachers in Low-SES Schools.” PhD diss., Washington State University. https://research.libraries.wsu.edu/xmlui/bitstream/handle/2376/5197 /Hill_wsu_0251E_11186.pdf.

Intel Corporation. 2014. "Assessment and Next Generation Science Standards." https:/www.intel .com/content/dam/www/program/education/us/en/documents/assessing-projects/common-core /Assessment-Science.pdf.

International Reading Association. 2005. "Diagnostic Teaching for Primary Level Schooling. Program Overview: What is Diagnostic Teaching?"

Jamalzadeh, Masoumeh, and Zahra Shahsavar. 2015. "The Effects of Contextual Factors on Teacher's Beliefs and Practices." Procedia - Social and Behavioral Sciences 192: 166-71. https://doi.org/10.1016 /j.sbs pro.2015.06.024.

Jang, Eunice Eunhee, and Maryam Wagner. 2013. “Diagnostic Feedback in the Classroom.” In The Companion to Language Assessment, Volume II. Approaches and Development, edited by Antony John Kunnan, 693-711. New York: Wiley-Blackwell. https://doi.org/10.1002/9781118411360.wbcla081.

Mathiesen Gilje, Trine. 2014. "Teacher Cognition and the Teaching of EFL Reading in Norwegian Upper Primary Classrooms.” Acta Didactica Norge 8 (2): 1-17. https://doi.org/10.5617/adno.1141.

Mussawy, Sayed Ahmad Javid. 2009. "Assessment Practices: Students' and Teachers' Perceptions of Classroom Assessment.” MA thesis, University of Massachusetts. https://scholarworks.umass.edu/cgi /viewcontent.cgi?article=1008\&context=cie_capstones.

Nikolov, Marianne. 2016. “A Framework for Young EFL Learners' Diagnostic Assessment: 'Can Do Statements' and Task Types." In Assessing Young Learners of English: Global and Local Perspectives, edited by Marianne Nikolov, 65-92. New York: Springer. 
Ofodu, Graceful Onovughe, and Olusegun O. Owolewa. 2017. "Evaluating the Linguistic and Pedagogical Skills of English Language Teachers in Multilingual Milieu." Research Journal of Education 4 (6): 87-91.

Olagunju, Asimiyu Moyosore. 2015. "The Effect of Formative Assessment on Students' Achievement in Secondary School Mathematics.” International Journal of Education and Research 3 (10): 481-90. http://www.ijern.com/journal/2015/October-2015/37.pdf.

Organisation for Economic Co-operation and Development 2005. "Formative Assessment: Improving Learning in Secondary Classrooms." https://www.oecd.org/education/ceri/35661078.pdf.

Ounis, Tesnim. 2017. "Exploring Secondary Teachers' Perceptions of Classroom Assessment in a Tunisian Context." International Journal of Language and Linguistics 4 (2): 116-24. http://ijllnet.com/journals /Vol_4_No_2_June_2017/15.pdf.

Pereira, Diana R., and Maria Assunção Flores. 2016. "Conceptions and Practices of Assessment in Higher Education: A Study of Portuguese University Teachers." Revista Iberoamericana de Evaluación Educativa 9 (1): 9-29. https://doi.org/10.15366/riee2016.9.1.001.

Plake, Barbara S., and James C. Impara. 1997. "Teacher Assessment Literacy: What Do Teachers Know about Assessment?" In Handbook of Classroom Assessment: Learning, Achievement, and Adjustment, edited by Gary D. Phye, 53-58. San Diego: Academic Press.

Pradhan, Bhabagrahi. 2014. "Diagnostic Evaluation and Remedial Instructions for BEd Students in English Language Teaching in Sekhawati Area of Rajasthan.” http://hdl.handle.net/10603/183268.

Price, Jon K., Elizabeth Pierson, and Daniel Light. 2011. "Using Classroom Assessment to Promote 21st Century Learning in Emerging Market Countries." Global Learn Asia Pacific 2011, March 28-April 1, 2011, Melbourne, Australia.

Reed, Daniel. 2006. "Diagnostic Assessment in Language Teaching and Learning." Clear News 10 (2): 1-5.

Sethusha, Mantsose Jane. 2012. "An Investigation of the Challenges Affecting Teachers' Classroom Assessment Practices." PhD diss., University of South Africa.

Shim, George Tan Geok, Abang Mohammad Hudzaifah Abang Shakawi, and Farah Liyana Azizan. 2017. "Relationship between Students' Diagnostic Assessment and Achievement in a Pre-University Mathematics Course." Journal of Education and Learning 6 (4): 364-71. https://doi.org/10.5539/jel .v6n4p364.

Siamak, Rahimi. 2014. "Teacher Cognition Vis-à -Vis Vocabulary Teaching." Theory and Practice in Language Studies 4 (3): 652-60. https://doi.org/10.4304/tpls.4.3.652-660.

Stevens, Joe. 2009. Washington State Diagnostic Assessment Guide. Olympia, WA: Office of Superintendent of Public Instruction.

Sun, Yuan, and Masayuki Suzuki. 2013. "Diagnostic Assessment for Improving Teaching Practice." International Journal of Information and Education Technology 3 (6): 607-10. https://doi.org/10.7763 /IJIET.2013.V3.345.

Susuwele-Banda, William John. 2005. “Classroom Assessment in Malawi: Teachers' Perceptions and Practices in Mathematics.” PhD diss., Virginia Polytechnic Institute and State University.

Targema, Numbe Terwase, and Oluwatoyin C. Obadare-Akpata. 2018. "Diagnostic Assessment: A Tool for Quality Control in Education.” Journal of Educational Research and Review 1 (1): 17-24.

Treagust, David F. 2006. "Diagnostic Assessment in Science as a Means to Improving Teaching, Learning and Retention." In Proceedings of the Assessment in Science Teaching and Learning Symposium (2006), 1-9.

Walsh, Rupert, and Mark Wyatt. 2014. "Contextual Factors, Methodological Principles and Teacher Cognition." Studies in Second Language Learning and Teaching 4 (3): 693-718. https://doi.org/10 .14746/ssllt.2014.4.4.6.

Yunus, Melor, Hadi Salehi, and Mahdi Amini. 2016. "EFL Teachers' Cognition of Teaching English Pronunciation Techniques: A Mixed-Method Approach.” English Language Teaching 9 (2): 21-42. https://doi.org/10.5539/elt.v9n2p20.

Zhao, Zhongbao. 2013. "An Overview of Studies on Diagnostic Testing and its Implications for the Development of Diagnostic Speaking Test." International Journal of English Linguistics 3 (1): 41-45. 